\title{
Clinical Observation Result Category
}

National Cancer Institute

\section{Source}

National Cancer Institute. Clinical Observation Result Category. NCI Thesaurus. Code C102741.

A classification of a clinical observation result. 